\title{
Species, diversity, and density affect tree seedling mortality from Armillaria root rot
}

\author{
J .P. Gerlach, P.B. Reich, K. Puettmann, and T. Baker
}

\begin{abstract}
Mortality from Armillaria root rot is a major concern of forest management. Field experiments were conducted in Minnesota to evaluate interspecific differential susceptibility and to assess whether density or species composition, specifically the proportion of conifers in a plot, influences seedling mortality from Armillaria spp. Seedlings of 10 tree species (six conifers and four hardwoods) were planted at four densities in several species mixtures on recently logged sites. Species differed significantly in susceptibility ( $p<0.0001$ ); balsam fir (Abies balsamea (L.) Mill.), tamarack (Larix laricina (Du Roi) K. Koch), and black spruce (Picea mariana (Mill.) BSP) showed the greatest infection and mortality. Hardwood species and eastern white pine (Pinus strobus L.) showed negligible mortality. There was a trend $(p=0.1)$ toward increased root infection with increasing density of the three species that showed significant mortality. Their mortality rates were 5.6, $8.7,10.2$, and $10.8 \%$ in plots with $2-, 1-, 0.5-$, and $0.25-\mathrm{m}$ spacing, respectively. Mortality increased significantly $(p=0.001)$ with an increase in the proportion of conifers in a plot. Mortality in the three most susceptible species was reduced by $75 \%$ when grown in aspen-rich rather than in conifer-rich plots. Thus, seedling mortality was related to species identity, planting density, and proportion of conifers, suggesting that selected diversity (mixtures of conifers with hardwoods rather than conifer monocultures) reduces disease impact.
\end{abstract}

Résumé : La mortalité due à la carie de racine causée par Armillaria est une préoccupation importante en aménagement forestier. Des expériences au champ furent menées au Minnesota dans le but d'évaluer la sensibilité interspécifique et de vérifier si la densité ou la composition en espèces, plus particulièrement la proportion de conifères dans une parcelle, influencent la mortalité des semis causée par Armillaria spp. Les semis de 10 espèces d'arbres (six conifères et quatre feuillus) furent plantés selon quatre densités et plusieurs combinaisons d'espèces sur des sites récemment coupés. La sensibilité différait de façon significative ( $p<0,0001)$ selon l'espèce : le sapin baumier (Abies balsamea (L.) Mill.), le mélèze laricin (Larix laricina (Du Roi) K. Koch) et l'épinette noire (Picea mariana (Mill.) BSP) avaient le plus fort taux d'infection et de mortalité. Les espèces feuillues et le pin blanc (Pinus strobus L.) avaient un taux de mortalité négligeable. L'infection des racines augmentait $(p=0,1)$ avec la densité des trois espèces qui avaient un taux de mortalité important. Leur taux de mortalité atteignait respectivement 5,6,8,7,10,2 et 10,8\% dans les parcelles avec un espacement de 2, 1, 0,5 et $0,25 \mathrm{~m}$. La mortalité augmentait de façon significative $(p=0,001)$ avec la proportion de conifères dans la parcelle. La mortalité des trois espèces les plus sensibles était réduite de $75 \%$ lorsque ces espèces étaient cultivées dans des parcelles contenant beaucoup de peupliers faux-tremble plutôt que dans des parcelles qui contenaient beaucoup de conifères. Par conséquent, la mortalité des semis était reliée à l'identité des espèces, à la densité de la plantation et à la proportion de conifères, suggérant qu'en choisissant la diversité (mélanges de conifères et de feuilllus plutôt que des monocultures de conifères) on diminue l'impact de la maladie.

[Traduit par la Rédaction]

\section{Introduction}

Since Robert Hartwig published his classic work "Wichtige Krankheiten der Waldbaume" in 1874, Armillaria root rot has been the subject of intensive basic and applied research that has provided a better understanding of biological characteristics of Armillaria spp. and their prevalence, virulence, and geo-

Received December 11, 1996. Accepted May 4, 1997.

J.P. Gerlach, P.B. Reich, ${ }^{1}$ K. Puettmann, and T. Baker. Department of Forest Resources, University of Minnesota, 1530 N. Cleveland Ave., St. Paul, MN 55108, U.S.A.

1 Author to whom all correspondence should be addressed. e-mail: preich@forestry.umn.edu graphic distribution and of management alternatives (Shields and Hobbs 1979; Wargo and Shaw 1985; Shaw and Kile 1991; Blodgett and Worrall 1992a, 1992b). Research needs that remain include the relative importance of hosts and local conditions on disease expression and impacts (Shaw and Kile 1991). For example, there is little information about how tree density, species composition, and diversity via proportion of conifer seedlings affect the patterns of disease. There are few common garden tests of interspecific differential susceptibility.

The objective of this study was to determine seedling mortality due to Armillaria spp. as part of a long-term experiment on the effects of density, species composition, and competition on seedling growth and establishment. Inasmuch as disease dynamics may sometimes be related to spatial patterns, we hypothesized that both decreasing density and increasing 
Table 1. Plot design components for random plots, aspen-rich plots, and spruce-rich plots.

\begin{tabular}{lcccc}
\hline Composition & $\begin{array}{c}\text { Proportion } \\
\text { (conifer/hardwood) }\end{array}$ & $\begin{array}{c}\text { Density } \\
\text { (spacing, m) }\end{array}$ & $\begin{array}{c}\text { No. of plots } \\
\text { (replicates) }\end{array}$ & Experiment \\
\hline Random & $60 / 40$ & 2 & 3 & 1 \\
& $60 / 40$ & 1 & 5 & 1 \\
& $60 / 40$ & 0.5 & 4 & 1,2 \\
Aspen rich & $60 / 40$ & 0.25 & 4 & 1,2 \\
White spruce rich & $30 / 70$ & 0.5 & 3 & 2 \\
& $30 / 70$ & 0.25 & 3 & 2 \\
\hline
\end{tabular}

Note: All plots had 12 rows of 12 trees. Random plots had equal numbers of all 10 species randomly assigned to positions within and among rows. Aspen-rich and spruce-rich plots were identical to random plots except that alternating rows of aspen or spruce, respectively, replaced 10-species rows. Experiment 1 involved a density gradient and Experiment 2 assessed composition effects (proportion of conifers).

diversity (such as mixtures rather than monocultures, and represented in this study as a decreasing proportion of conifers in a plot) would be associated with lower mortality rates.

\section{Materials and methods}

Two sites were selected for long-term experiments on the Cloquet Forestry Center, Cloquet, Minnesota, U.S.A. $\left(46^{\circ} 43^{\prime} \mathrm{N}, 92^{\circ} 28^{\prime} \mathrm{W}\right)$. Prior to harvest, one site was occupied by a multiaged aspen stand with $18-23 \mathrm{~m}^{2}$ basal area/ha, while the other was a sparse old-growth mature red and white pine stand with paper birch (Betula papyrifera Marsh.), aspen (Populus spp.), and mixed conifer understory (basal area $14-18 \mathrm{~m}^{2} / \mathrm{ha}$ ). Both sites were clearcut in the winter of 1991-1992, 6 months prior to the study establishment. Slash was piled and burned, but no other site preparation treatments were applied. Soils throughout both sites were Boralfisols (sandy loams/loamy sands).

The study design included planting (in 1992) 10 northern hardwood and boreal tree species common in the western Great Lakes region in an assortment of experimental densities and species combinations. Twenty-eight plots, ranging from 9 to $400 \mathrm{~m}^{2}$ in size, were established (Table 1). The 10 species were trembling aspen (Populus tremuloides Michx.), black spruce (Picea mariana (Mill.) BSP), jack pine (Pinus banksiana Lamb.), red oak (Quercus rubra L.), balsam fir (Abies balsamea (L.) Mill.), sugar maple (Acer saccharum Marsh.), tamarack (Larix laricina (Du Roi) K. Koch), eastern white pine (Pinus strobus L.), white spruce (Picea glauca (Moench) Voss), and yellow birch (Betula alleghaniensis Britton).

The study consisted of two experiments that together comprise an incomplete factorial design of species mixtures and densities (total of approximately 4000 seedlings). Random plots contained 14 or 15 seedlings of each of the 10 species (144 seedlings arranged in 12 rows of 12 seedlings) planted at 0.25-, 0.5-, 1.0-, and 2.0-m spacings in separate plots. Seedlings were randomly assigned positions in the $12 \times 12$ seedling grid. The first experiment (No. 1) examined species responses across the density gradient (Table 1). An additional experiment (No. 2) consisted of three kinds of species mixtures at the two highest densities (0.25- and 0.5-m spacings). The species mixtures (Table 1) included (i) 60\% conifers (all 12 rows of 10-species mixtures, i.e., random plots), (ii) $80 \%$ conifers (six alternating rows of the 10 -species mixtures with six rows of white spruce, i.e., sprucerich plots), and (iii) $30 \%$ conifers (six alternating rows of the 10species mixture with six rows of aspen, i.e., aspen-rich plots).

From mid-July to mid-October 1994, a biweekly inspection of all plots provided mortality counts. The seedlings were classified as infected by Armillaria spp. if evidence of pathogen was present (Shaw and Kile 1991). This evidence included creamy white mycelial fans; rhizomorphic growth (white $<1 \mathrm{~cm}$ and red-brown, brown, and black $>1 \mathrm{~cm}$ ); cankers, cracks, or flutes at the base of the stem; decay, white rot of woody tissue due to decomposition of lignin and cellulose; and appearance of "zone lines" in decaying tissue (Hepting 1971; Shaw and Kile 1991). The single piece of evidence found on all infected seedlings, and sufficient for determination of infection, was the presence of white mycelial fans (R. Blanchette, personal communication). Isolation of fungi for species identification was not done. However, isolates from 278 hosts (stumps, and conifer and hardwood regeneration) and 78 solitary basidiomes from three plots on recently clearcut stands on the Cloquet Forestry Center were all identified as Armillaria ostoyae Romagn. (Rizzo et al. 1995). Thus, this is the most likely species in our plots (R. Blanchette, personal communication). We tested treatment main effects and interactions with likelihood ratio chi-square tests using a logistic regression model (JMP, SAS Institute, Cary, NC 27511). Likelihood ratio tests were calculated as twice the difference of the log likelihoods between the full model and the model constrained by the effect(s) to be tested (i.e., the model without the effect). To ensure a sufficient number of dead seedlings for reliable analysis, the tests of density and species composition used only a subset of species.

\section{Results}

To maintain a balanced species $\times$ density factorial, the analyses of species and density effects on overall mortality were done using only the plots where all rows contained the 10 -species mixture (Experiment 1, Table 1). There were no significant interactions and the only significant factor was species $(p=$ 0.04). Balsam fir, tamarack, and black spruce had the greatest mortality, with sugar maple, white pine, red oak, and yellow birch showing negligible mortality. Percent mortality per species was similar using the entire data set (Fig. 1). Aspen was the only hardwood species with more than one dead seedling, and there were no signs of root disease on any aspen seedling. In all six conifer species, between 50 and $90 \%$ of the dead seedlings were infected with Armillaria spp.. There was a linear correlation $\left(p<0.001, r^{2}=0.84\right)$ among the 10 species between the total number of dead and the number of dead identified as Armillaria infected. There was also a significant correlation (Spearman's rho, $p=0.01$ ) between the number of Armillaria-infected and number of dead seedlings not associated with Armillaria across all species and plots (i.e., treatment combinations). For brevity the total number of dead conifer seedlings is used as an index of Armillariainduced mortality. Results are similar if infected dead seedlings alone are used in analyses. 
Fig. 1. Percent mortality $( \pm \mathrm{SE})$ of 10 species across all plots ( $n=28$, pooling across all densities and species neighborhoods). Species are arranged from left to right by conifer and hardwood groups, and within groups by highest to lowest mortality. Species differed significantly in mortality $(p=0.04)$.

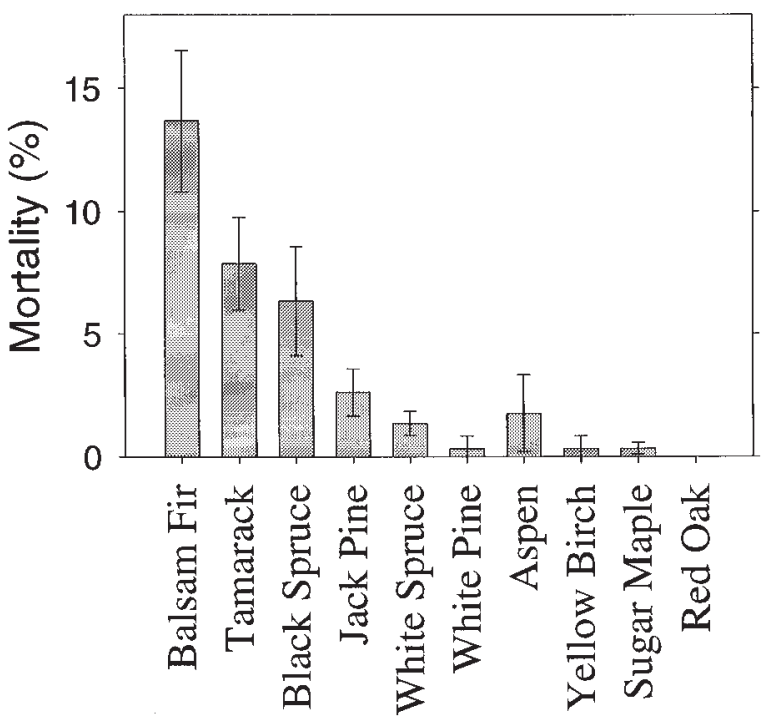

Fig. 2. Percent mortality ( \pm SE) of balsam fir, tamarack, and black spruce (data pooled) grown at four spacings using data from randomly selected 10 -species mixture plots. Density was significant at $p=0.1$.

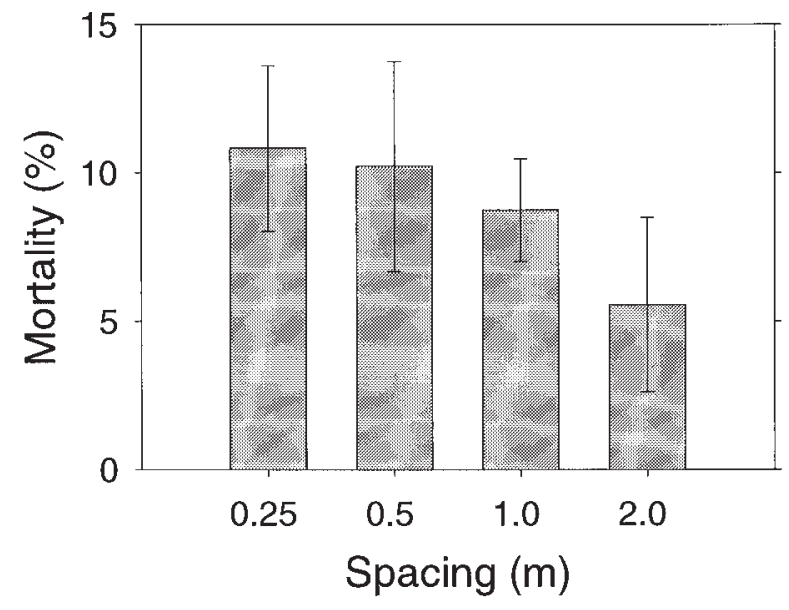

Three conifer species (balsam fir, tamarack, and black spruce) showed at least twice the mortality rate of the other species (Fig. 1). Therefore, we focused on these species for further analyses of density and compositional effects. In logistic regressions analysis, there was no species $\times$ density interaction, but there was a tendency $(p=0.10)$ for mortality to increase at higher density (Fig. 2). Mortality rates for these three species pooled were $5.6,8.7,10.2$, and $10.8 \%$ in plots with $2-, 1-, 0.5-$, and $0.25-\mathrm{m}$ spacing, respectively.

In logistic regression analysis for the same three species in the three different plot mixtures (at the two highest densities), the species $\times$ composition interaction was not significant $(p>0.25)$, density was not significant $(p>0.25)$, species
Fig. 3. Percent mortality ( \pm SE) of balsam fir, tamarack, and black spruce grown in three different plots that correspond to $80 / 20$, $60 / 40$, and $30 / 70 \%$ conifer/hardwood ratios, respectively (alternating rows of white spruce with rows of the 10-species mixture, all rows of the 10-species mixture, and alternating rows of aspen with the 10-species mixture). The alternative mixtures differed significantly $(p=0.001)$ (i.e., species composition was a significant effect). Data pooled across spacing treatments.

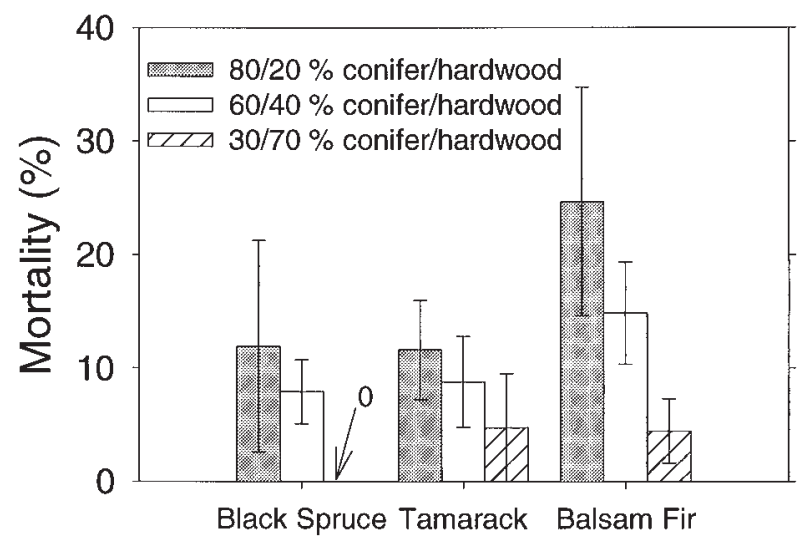

was marginally significant (at $p=0.06$ ), and composition (species mixture) was highly significant $(p=0.001)$. Plots with increasing dominance by conifers showed higher mortality in all three species (Fig. 3). In plots with $80 \%$ conifers (those with alternate white spruce rows), mortality across the three conifers was approximately $10-25 \%$. In contrast, plots with alternate aspen rows (and a total of $30 \%$ conifers) had 0-5\% mortality in each species (Fig. 3).

\section{Discussion}

These data support published reports that conifers (less so red, white, and jack pine than balsam fir, white spruce, and tamarack) are more susceptible to Armillaria spp. infection than hardwoods (for review, see Schwertfeger 1981; Wargo and Harrington 1991). In addition, a tendency for higher infection and mortality was evident in plots with overall greater density (and thus, greater conifer density) or plots with a greater abundance of conifers (and thus, greater conifer density). These findings suggest that species or functional group diversity might generally influence seedling infection and mortality, since the proportion (and thus, overall density) of conifers declines as one moves from conifer near-monocultures to mixtures that include greater numbers and abundance of hardwood species. This is analogous to decreasing balsam fir defoliation by spruce budworm as the proportion of fir declines from nearly 100 to $20 \%$ (Su et al. 1996). It is unlikely that competitive stress predisposed trees to infection and mortality (Risbeth 1983; Davidson and Risbeth 1988) because trembling aspen had the highest growth rates and is one of the strongest competitors for resources (T. Baker, P.B. Reich, and K. Puettmann, unpublished data), yet aspen-rich plots showed low mortality. Similarly, it is unlikely that planting stress led to increased susceptibility of some species (Davidson and Risbeth 1988), especially because susceptibility was also related to species composition. All seedlings were treated the same and planted by the same crews. Also, the plots were randomly located 
throughout the sites, and differential site adaptation should affect different species similarly in all plots.

There are long-standing claims for the benefits of biodiversity, including lower disease incidence (e.g., Pimm 1984). However, there are few experimental tests of these claims. Data from this study suggest that either greater species diversity (addition of aspen in this case) or functional group diversity (mixtures of hardwoods with conifers) contributes to lesser infection and mortality. How might this occur? Conifer density affects disease incidence and mortality. Reduced conifer density was associated with reduced mortality. A parsimonious hypothesis is that an inverse relationship between species density and diversity influences mortality. Specifically, greater diversity results in a lower density of any single species, which could lead to lower infection/mortality because of the lowered chance of infectious contact. It is important to note that in this study the pathogen in question is predisposed towards conifers rather than hardwoods, and more virulent on such species. The value of mixed stands might not exist to the same extent for a generalist pathogen. Thus, managers need to know which species of Armillaria (or any other disease agent) is present, and whether it has a wide or narrow host range, to evaluate whether manipulation of species composition and (or) diversity might work as a management option. Implications for management are premature, moreover, because site and stand level factors as well as other factors (Wargo and Shaw 1985; Blodgett and Worrall 1992a, 1992b) likely affect the relative impact of species composition and diversity on disease. Nonetheless, consideration of the potential value of mixed-species forests is warranted.

\section{Acknowledgments}

Thanks to the Wilderness Research Foundation, Interagency Terrestrial Ecology and Global Change Program (NSF DEB9524078), Minnesota Agricultural Experiment Station, McIntire-Stennis Program, and Undergraduate Research Opportunities Program of Minnesota for financial support and to Dr. Robert Blanchette for assistance with various aspects of this project.

\section{References}

Blodgett, J.T., and Worrall, J.J. 1992a. Distributions and hosts of Armillaria species in New York. Plant Dis. 26: 166-170.

Blodgett, J.T., and Worrall, J.J. 1992b. Site relationships of Armillaria species in New York. Plant Dis. 26: 170-174.

Davidson, A.J., and Risbeth, J. 1988. Effect of suppression and felling on infection of oak and Scotch pine by Armillaria. Eur. J. For. Pathol. 18: 161-168.

Hartwig, R. 1874. Wichtige Krankheiten der Waldbäume. Beiträge sur Mycologie und Phytopathologie für Botaniker und Forstmänner. Springer-Verlag, Berlin. [Important diseases of forest trees. Contributions to mycology and phytopathology for botanists and foresters. Phytopathological Classics No. 12. 1975. American Phytopathological Society, St. Paul, Minn.].

Hepting, G.H. 1971. Diseases of forest and shade trees of the United States. USDA For. Ser. Agric. Handb. No. 386.

Pimm, S.L. 1984. The complexity and stability of ecosystems. Nature (Lond.), 307: 321-326.

Risbeth, J. 1983. The importance of the honey fungus (Armillaria) in urban forestry. Arboricult. J. 7: 217-225.

Rizzo, D.M, Blanchette, R.A., and May, G. 1995. Distribution of Armillaria ostoyae genets in a Pinus resinosa - Pinus banksiana forest. Can. J. Bot. 73: 776-787.

Schwertfeger, F. 1981. Die Waldkrankheiten. Verlag Paul Parey, Hamburg.

Shaw, C.G. III, and Kile, G.A. (Editors). 1991. Armillaria root disease. USDA For. Serv. Agric. Handb. No. 691. pp. iii-iv.

Shields, W.J. Jr., and Hobbs, S.D. 1979. Soil nutrient levels and pH associated with Armillaria mellea on conifers in northern Idaho. Can. J. For. Res. 9: 45-48.

Su, Q., MacLean, D.A., and Needham, T.D. 1996. The influence of hardwood content on balsam fir defoliation by spruce budworm. Can. J. For. Res. 26: 1620-1628.

Wargo, P.M., and Harrington, T.C. 1991. Host stress and susceptibility. In Armillaria root disease. Edited by C.G. Shaw III and G.A. Kile. USDA For. Serv. Agric. Handb. No. 691. pp. 88-181.

Wargo, P.M., and Shaw, C.G. III. 1985. Armillaria root rot: the puzzle is being solved. Plant Dis. 69: 826-832. 